\title{
sciendo
}

CIVIL AND ENVIRONMENTAL ENGINEERING REPORTS

E-ISSN 2450-8594

CEER 2018; 28 (2): 124-139

DOI: $10.2478 /$ ceer-2018-0024

Original Research Article

\section{THE USE OF SODIUM PERCARBONATE IN THE FENTON REACTION FOR THE PAHS OXIDATION}

\author{
Jolanta KOZAK, Maria WŁODARCZYK - MAKUŁA ${ }^{1}$ \\ Czestochowa University of Technology, Częstochowa, Poland
}

\begin{abstract}
The aim of the paper was to determine the effectiveness of the removal of 4, 5and 6 - ring PAHs from coking wastewater using sodium percarbonate $\mathrm{Na}_{2} \mathrm{CO}_{3} \cdot 1,5 \mathrm{H}_{2} \mathrm{O}_{2}$ and iron sulphate in acid condition. The samples were exposing to ultraviolet rays. The source of UV-C radiation was a lamp emitting a wave of light with a length of $\lambda=264 \mathrm{~nm}$, placed directly above the layer of the samples wastewater. The sodium percarbonate $\mathrm{Na}_{2} \mathrm{CO}_{3}$ $1.5 \mathrm{H}_{2} \mathrm{O}_{2}$ doses were determined on the basis of stoichiometric calculation. Ratio of iron ions to the hydrogen peroxide released in reaction was: $0.5 ; 0.4 ; 0.3 ; 0.2 ; 0.1$. Before and after the oxidation process, COD and TOC value were determined and as well as concentrations of selected PAHs. The total concentration of tested PAHs before oxidation reached the value of $995 \mu \mathrm{g} / \mathrm{L}$. The average content of organic pollutants determined by the chemical oxygen demand (COD) was $538 \mathrm{mg} / \mathrm{L}$, while the average content of Total organic carbon (TOC) was $180 \mathrm{mg} / \mathrm{L}$. The use of sodium percarbonate caused the oxidation of organic pollutants and lowering of COD and TOC in the following ranges: $22-46 \%$ and $10-30 \%$. For individual PAHs the degradation efficiency was in the ranged from $95 \%$ to $99.9 \%$. The degradation efficiency of 4 ring hydrocarbons caused $98 \%$ and 5 and 6 ring of hydrocarbons was $98.7 \%$ and $99.4 \%$, respectively.
\end{abstract}

Keywords: photo-Fenton oxidation, sodium percarbonate, GC-MS, coking wastewater, PAHs

\footnotetext{
${ }^{1}$ Corresponding author: Czestochowa University of Technology, Department of Chemistry Water and Wastewater Technology, Dąbrowskiego st 69, 42-200 Częstochowa, Poland, e-mail: mwm@is.pcz.czest.pl, tel.+48343250919
} 


\section{INTRODUCTION}

Wastewater originated at the area of coking plants contains significant amounts of pollutants, including those belonging to the group of Persistent Organic Pollutants, among them Polycyclic Aromatic Hydrocarbons (PAHs) [1]. Polycyclic Aromatic hydrocarbons are composed of two or more aromatic rings linked together. Due to the number of rings, PAHs are classified into two groups, light and heavy PAHs. These compounds are easy adsorbed on the surface of solids, but they are non-easy degradable, so the use of conventional wastewater treatment methods is often not sufficient to remove PAHs [2-4]. Despite the use of biological wastewater treatment in the coking plant, with the use of activated sludge, treated coke wastewater are still carrier of PAHs as confirmed by literature reports and previous studies $[5,6]$. The further use of treated wastewater at the area of coking plant or entering into receivers $\mathrm{m}$ ay become impossible due to legal restrictions [7]. For the treatment of coke wastewater, advanced oxidation methods (AOP) are proposed. During the process a series of reactions takes place, based mainly on the formation and interaction of hydroxyl radicals for the destruction of organic pollutants $[8,9]$. One of the methods belonging to AOP is the photo-Fenton method, in which the Fenton reagent $\left(\mathrm{Fe}^{2+} / \mathrm{H}_{2} \mathrm{O}_{2}\right)$ and UV radiation are used. The formation of hydroxyl radicals in the photo-Fenton method proceeds according to reaction (1) (2) [10].

$$
\begin{gathered}
\mathrm{Fe}^{3+}+\mathrm{H}_{2} \mathrm{O}_{2}+\lambda v \rightarrow \mathrm{Fe}^{2+}+\mathrm{OH} \bullet+\mathrm{H}^{+} \\
\mathrm{H}_{2} \mathrm{O}_{2}+\lambda v(\mathrm{UV}) \rightarrow 2 \mathrm{HO} .
\end{gathered}
$$

Currently, the photo-Fenton method is modified by replacing hydrogen peroxide with other reagents that are a source of hydroxyl radicals. Metal oxides such as calcium or magnesium oxide are used, but also salt adducts with hydrogen peroxide such as sodium percarbonate $\mathrm{Na}_{2} \mathrm{CO}_{3} \bullet 1.5 \mathrm{H}_{2} \mathrm{O}_{2}$ [11]. However, this reagent has not been used so far for oxidation PAHs. Therefore the aim of survey have been undertaken to determine the degradation efficiency of selected PAHs present in treated coke wastewater using sodium percarbonate in the photo-Fenton process. Changes in the concentration of hydrocarbons containing from 4 to 6 aromatic rings in the molecule, i.e. belonging to the so-called heavy hydrocarbons have been analized. 


\section{MATERIALS AND METHODS}

\subsection{Materials}

The study carry out using preatreated coking wastewater, discharged from the biological treatment plant after the biological treatment process consists of the denitrification and nitrification reaction with use of activated sludge. Wastewater samples were characterized by determination of content organic compounds as COD and TOC value as well as the initial PAHs concentration.

\subsection{Experimental procedure}

The experiment carried out using 0,5 liter of coking wastewater. Researches on the oxidation of organic compounds, including PAHs, in wastewater samples were conducted in laboratory scale. The first step was added $\mathrm{Na}_{2} \mathrm{CO}_{3} \cdot 1.5 \mathrm{H}_{2} \mathrm{O}_{2}$ to the samples, then wastewaters were acidified and $\mathrm{FeSO}_{4} \cdot 7 \mathrm{H}_{2} \mathrm{O}$ iron sulfate was added. The dose of $\mathrm{FeSO}_{4} \cdot 7 \mathrm{H}_{2} \mathrm{O}$ iron sulfate was constant $(1 \mathrm{~g} / \mathrm{L})$. The dose of oxidant was calculated based on stoichiometric calculations. The reaction time was set at $20 \mathrm{~min}$. The next step was exposure wastewater samples to ultraviolet rays. In the studies following values were adopted as constant:

- dose $\mathrm{FeSO}_{4} \cdot 7 \mathrm{H}_{2} \mathrm{O}: 1 \mathrm{~g} / \mathrm{L}$,

- reaction time set at 20 minutes,

- exposure time to ultraviolet radiation of 8 minutes,

- the height of the irradiated wastewater layer was $2 \mathrm{~mm}$,

- $\mathrm{pH}$ value of wastewater 3.5-3.8.

Above research conditions such as $\mathrm{pH}$, reaction time and level of iron dose were selected based on data from the literature $[8,14,16]$. Sodium percarbonate was used as a solid (powder). The irradiation was carried out using a lamp emitting UV-C light with a wavelength $\lambda=264 \mathrm{~nm}$. The UV lamp has been placed above the level of wastewater. The irradiation was carried out in a plastic cuvette. Changes in COD and TOC values as well as the PAHs concentration were determined before and after oxidation process.

\subsection{PAHs analysis}

The first step was the extraction of organic substance from pretreated coking wastewater with use the cyclohexane and dichloromethane. The organic solvent solution in a volume ratio $5 / 1(\mathrm{v} / \mathrm{v})$ were added to the wastewater samples. Then the samples were shaken on a laboratory shaker for about 60 minutes. The next step was separation extract from the wastewater and cleaned on silica gel columns under vacuum conditions. After that, extract was concentrated under a stream of nitrogen and analyzed by GC-MS. The assay consists on injecting $2 \mu \mathrm{l}$ of the extract on the DB-5 column using helium as the carrier gas. The temperature 
program was $40^{\circ} \mathrm{C} / \mathrm{min}$ and the final temperature was $280^{\circ} \mathrm{C}$ for 60 minutes. In Table 1 limit of detection value and recovery rates of individual PAHs are presented. The following compounds were tested in the extract: 4-ring of PAHs (fluoranthene $\mathrm{Fl}$, pyrene Pyr, benzo(a)anthracene $\mathrm{BaA}$, chrysene $\mathrm{Ch}$ ) 5-ring of PAHs: (benzo(b)fluoranthene BbF, benzo(k)fluoranthene BkF, benzo(a)pyrene $\mathrm{BaP}$, dibenzo(ah)anthracene DahA) and containing 6-ring of PAHs (indeno(1,2,3cd) pyrene IP, benzo(g,h,i)perylene BghiP). PAHs were selected according to the US EPA list. Student's t-test was used to determine the significance of changes in the concentration of PAHs. The test was carried out in Statistica computer program. The test was selected based on the sample size $(n<30)$ for degrees of freedom (2), with the assumed significance level $\alpha=0.05$, the critical value obtained for the t-test was $t \approx 4.303$.

Table 1. Limit of detection and recovery for testes PAHs

\begin{tabular}{|c|c|c|c|}
\hline PAH & $\begin{array}{c}\text { Number of } \\
\text { rings }\end{array}$ & $\begin{array}{c}\text { Limit of detection } \\
{[\boldsymbol{\mu g} / \mathbf{L}]}\end{array}$ & $\begin{array}{c}\text { Recovery } \\
{[\%]}\end{array}$ \\
\hline Fluoranthene Fl & 4 & 0.1 & 81 \\
\hline Pyrene Pyr & 4 & 0.1 & 73 \\
\hline Benzo(a)anthracene BaA & 4 & 0.1 & 65 \\
\hline Chrysene Ch & 4 & 0.1 & 65 \\
\hline $\begin{array}{c}\text { Benzo(b)fluoranthene } \\
\text { BbF }\end{array}$ & 5 & 0.5 & 61 \\
\hline $\begin{array}{c}\text { Benzo(k)fluoranthene } \\
\text { BkF }\end{array}$ & 5 & 0.1 & 77 \\
\hline Benzo(a)pyrene BaP & 5 & 0.15 & 52 \\
\hline $\begin{array}{c}\text { Dibenzo(ah)anthracene } \\
\text { DahA }\end{array}$ & 5 & 0.2 & 54 \\
\hline $\begin{array}{c}\text { Indeno(123cd)pyrene IP } \\
\text { Benzo(ghi)perylene } \\
\text { BghiP }\end{array}$ & 6 & 0.15 & 68 \\
\hline
\end{tabular}

\section{RESULTS AND DISCUSSION}

Despite the initial pretreatment coking wastewater, the average organic pollutant determined by the chemical oxygen demand (COD) was $538 \mathrm{mg} / \mathrm{L}$, while the average content of total organic carbon (TOC) was $180 \mathrm{mg} / \mathrm{L}$. The initial concentration of the tested hydrocarbons was $995 \mu \mathrm{g} / \mathrm{L}$. During the oxidation process with using sodium percarbonate, the decrease in COD and TOC values was in the following range: $22-46 \%$ and $10-30 \%$, respectively. In Figures $1-4$ changes in the PAHs concentrations containing 4 aromatic rings per molecule are shown. The initial total concentration of 4-rings PAHs was $439 \mu \mathrm{g} / \mathrm{L}$. After 
oxidation process the concentration decreased for all dose of oxidant. The degradation efficiency was in the range of $95.4-98.8 \%$.

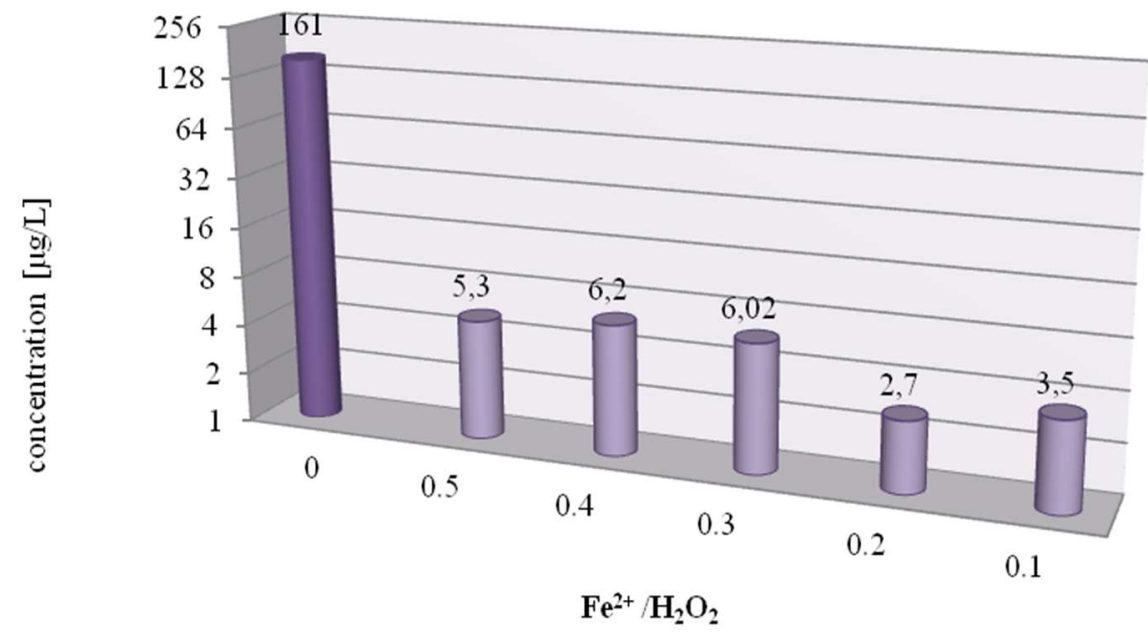

$\square$ wastewater before treatment $\square$ sodiumpercarbonate

Fig. 1. Changes in the concentration of fluoranthene

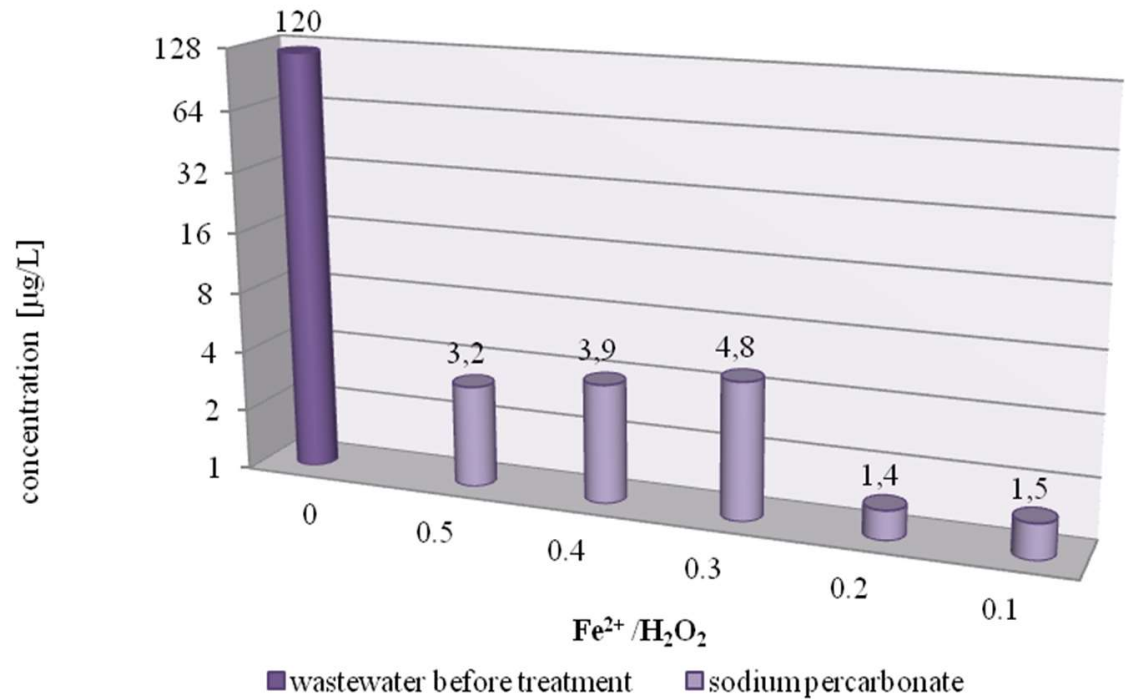

Fig. 2. Changes in the concentration of pyrene

The most effective in the degradation of fluoranthene (Fig. 1) was dose of sodium percarbonate corresponding to the ratio $0.2\left(\mathrm{Fe}^{2+} / \mathrm{H}_{2} \mathrm{O}_{2}\right)$. In this case degree of removal was $98.3 \%(2.7 \mu \mathrm{g} / \mathrm{L})$. For chrysene, pyrene and benzo(a) anthracene 
(Figs. 2-4) a ratio $0.2\left(\mathrm{Fe}^{2+} / \mathrm{H}_{2} \mathrm{O}_{2}\right)$ was also the most effective. Degree of removal of these hydrocarbons was above $98 \%$ which corresponded to the concentration of approx $1 \mu \mathrm{g} / \mathrm{L}$. The highest decrease in concentration for all 4-rings hydrocarbons was observed for the ratio 0.2 , but also the ratio $0.1\left(\mathrm{Fe}^{2+} / \mathrm{H}_{2} \mathrm{O}_{2}\right)$ allowed to achieve high oxidation efficiency. The average oxidation efficiency for the most effective ratio was around $98 \%$.

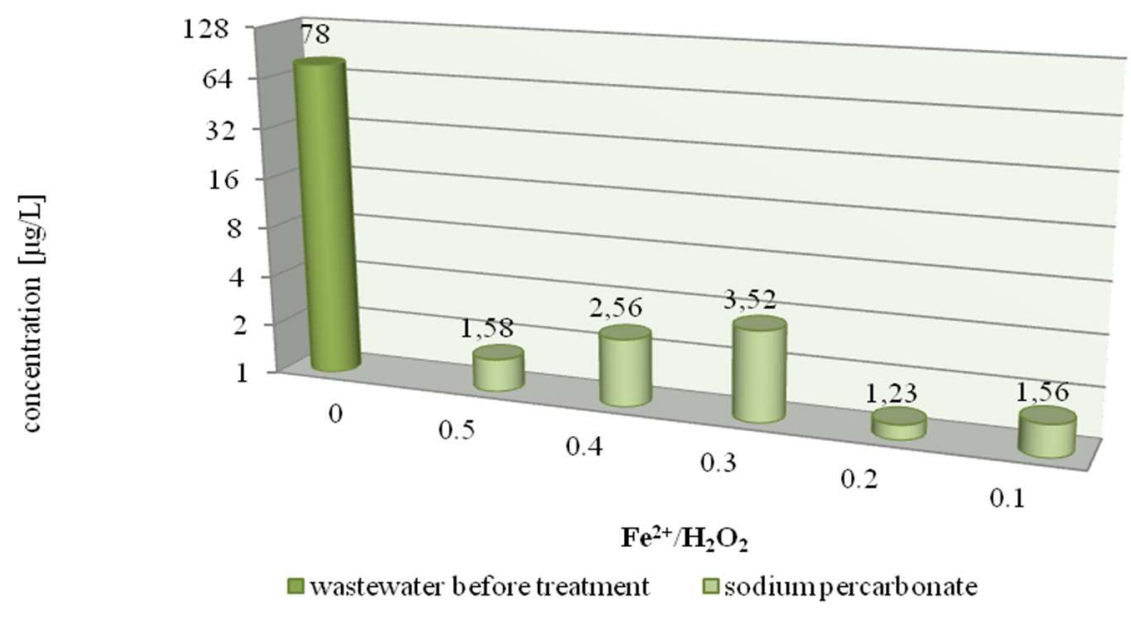

Fig. 3. Changes in the concentration of benzo(a)anthracene

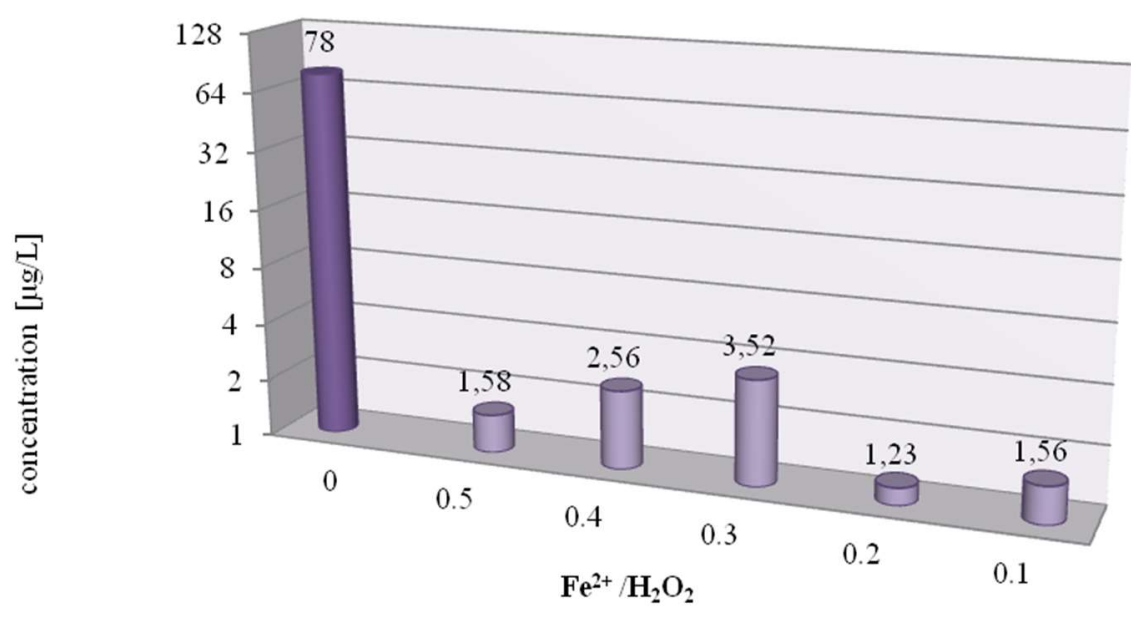

$\square$ wastewater before treatment $\square$ sodiumpercarbonate

Fig. 4. Changes in the concentration of chrysene 
The total initial concentration of 5-rings hydrocarbons was $425.5 \mu \mathrm{g} / \mathrm{L}$ which it was $43 \%$ of the total PAHs tested. In the figures 5-8 the changes in the concentration of 5-rings hydrocarbons depending on oxidant dose level has been shown.

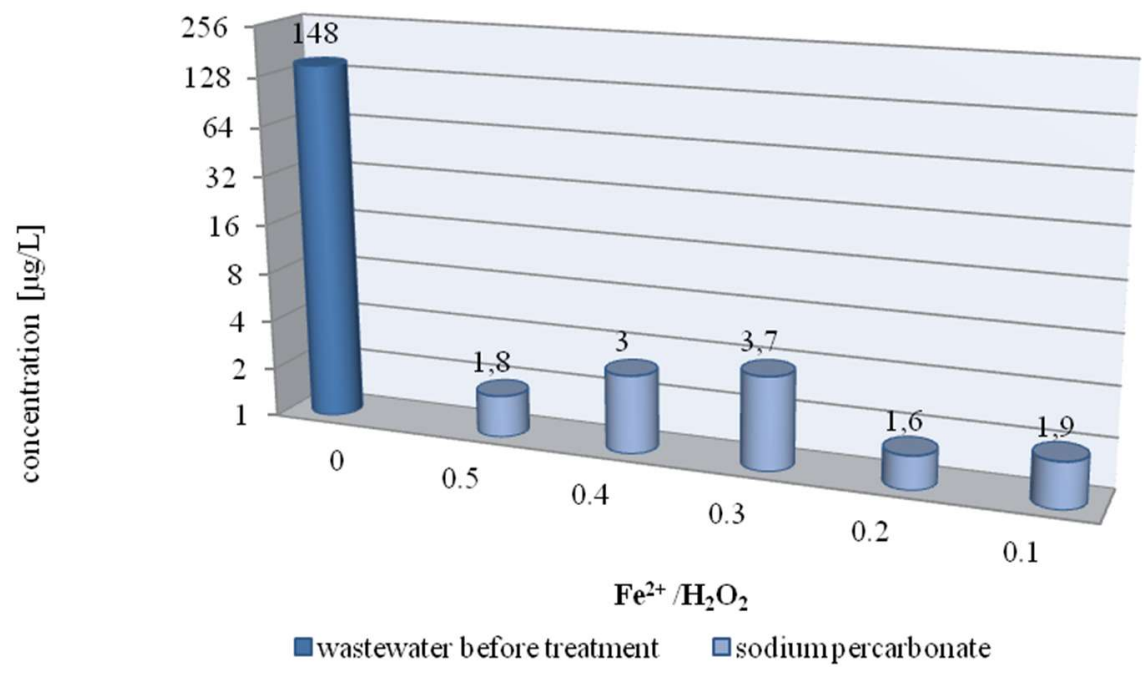

Fig. 5. Changes in the concentration of benzo(b)fluoranthene

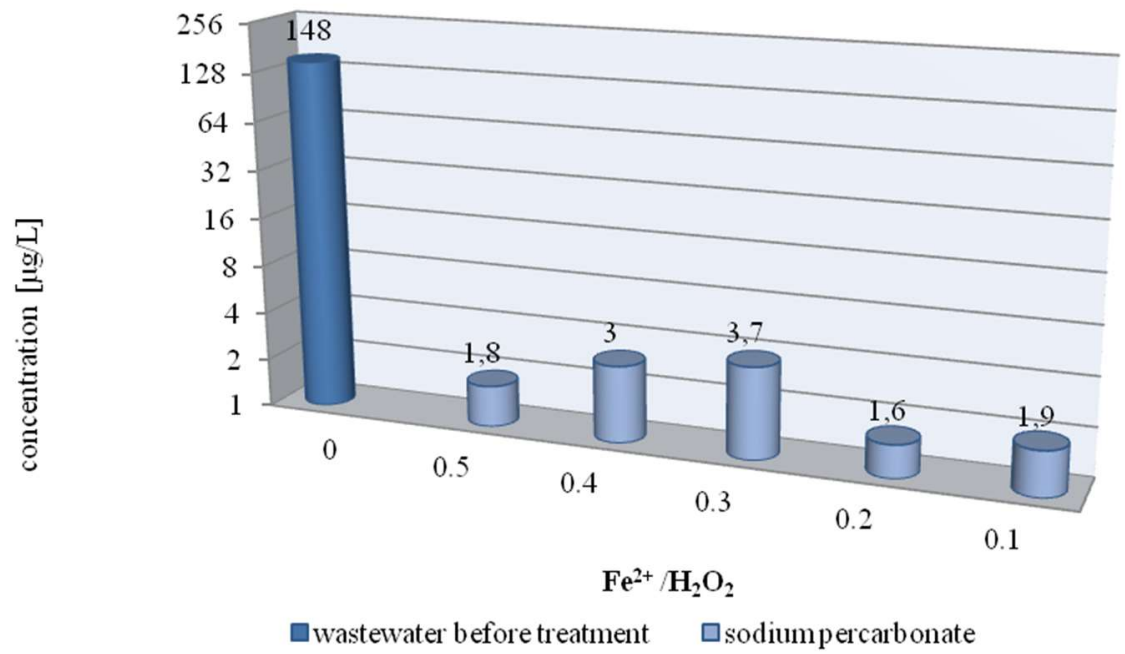

Fig. 6. Changes in the concentration of benzo(k)fluoranthene

The most effective degradation, in the case of benzo(b)fluoranthene (Fig. 5) and benzo(k)fluorantene (Fig. 6) was for the ratio $0.2 \mathrm{Fe}^{2+} / \mathrm{H}_{2} \mathrm{O}_{2}$. 


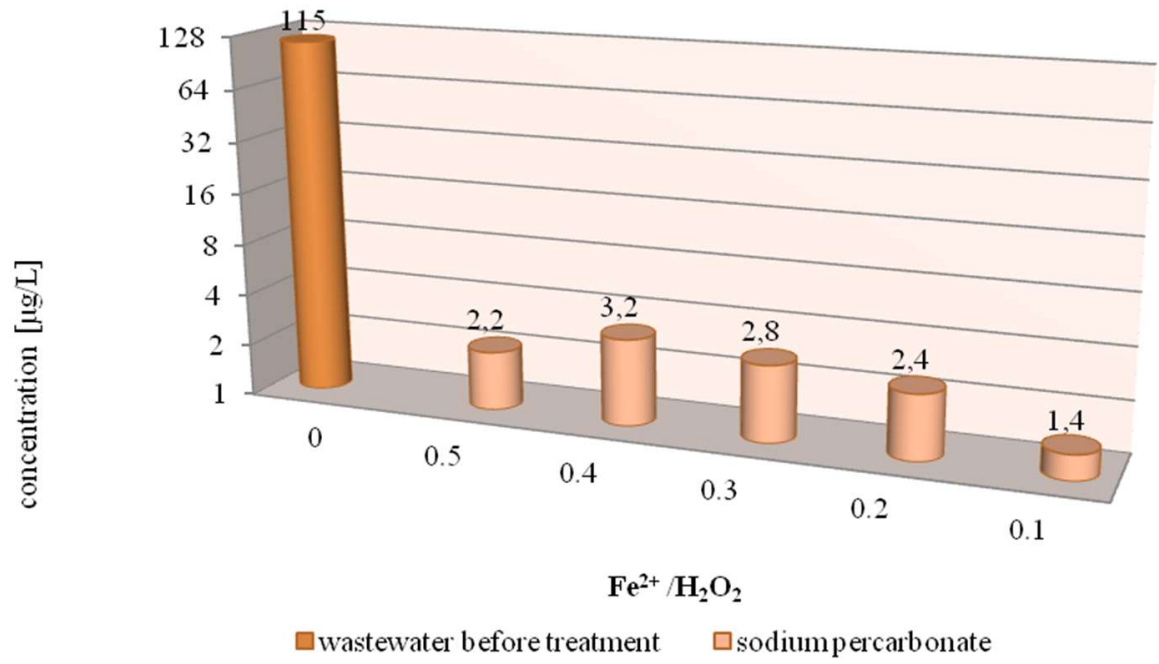

Fig. 7. Changes in the concentration of benzo(a)pyrene

The use of a dose of oxidant corresponding to a ratio $\mathrm{Fe}^{2+} / \mathrm{H}_{2} \mathrm{O}_{2}$ of 0.2 caused the oxidation of these two hydrocarbons in nearly $99 \%(1.6 \mu \mathrm{g} / \mathrm{L})$. However, the efficiency of ratio of 0.1 was similar. In the case of benzo(a)pyrene (Fig. 7) the highest degree of degradation $98.7 \%(1.4 \mu \mathrm{g} / \mathrm{L})$ was obtained for the 0.1 ratio of $\mathrm{Fe}^{2+} \mathrm{H}_{2} \mathrm{O}_{2}$. Dibenzo(a,h)anthracene (Fig. 8) was removed almost entirely, reaching a concentration below the limit of detection for the ratios of $0.5,0.2$ and 0.1 , respectively.

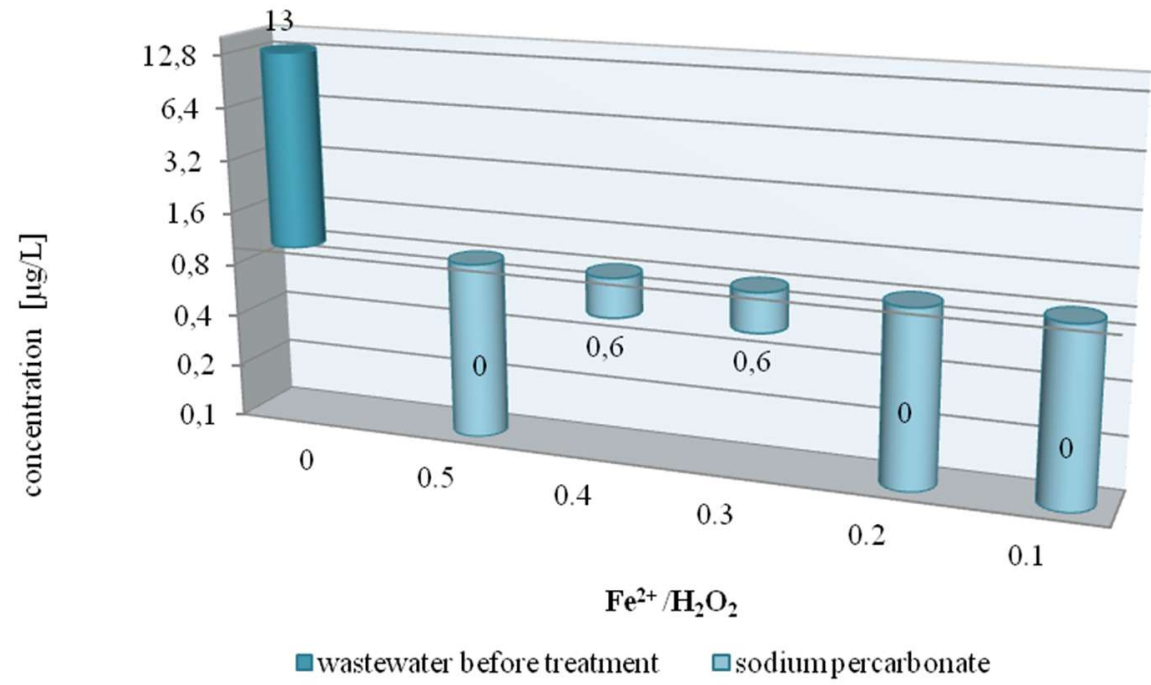

Fig. 8. Changes in the concentration of dibenzo(ah)anthtacene 
The total concentration of hydrocarbons containing 6 rings in the molecule was $130.8 \mu \mathrm{g} / \mathrm{L}$ which accounted for $13 \%$ of all PAHs tested. For indeno(1,2,3cd)pyrene (Fig. 9) and benzo(g,h,i)perylene (Fig. 10) the most effective was ratio 0.1 , which corresponded with the highest dose of sodium percabonate. Degree of degradation for this hydrocarbon was more than $99 \%$. The final concentration were 0.7 and $0.1 \mu \mathrm{g} / \mathrm{L}$ respectively.

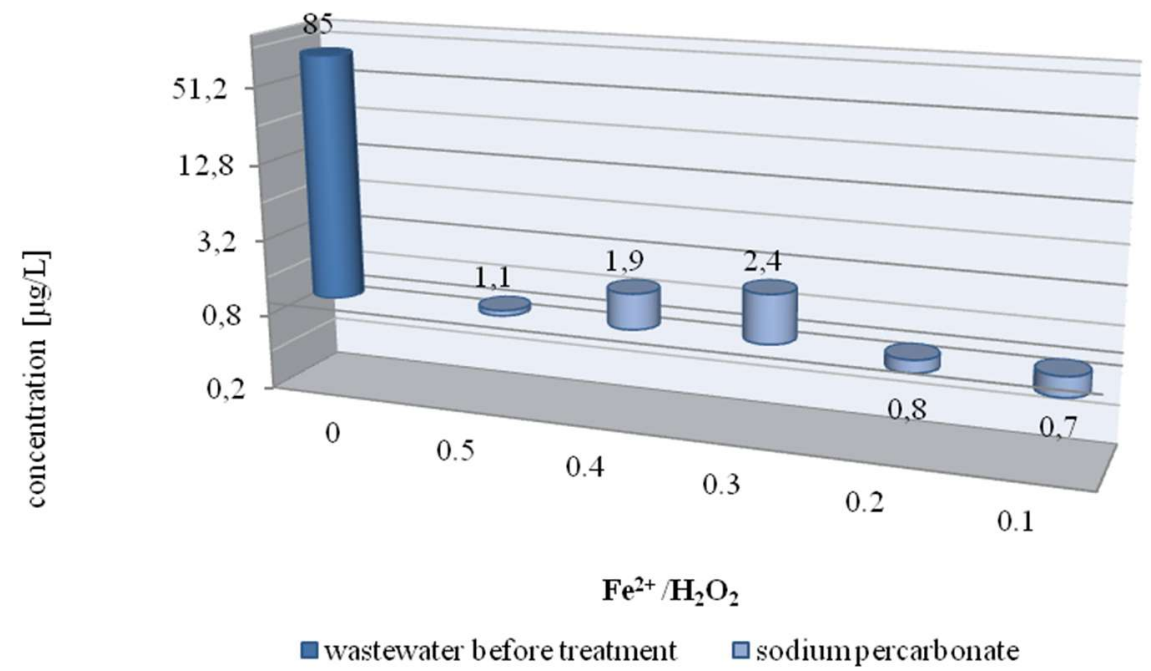

Fig. 9. Changes in the concentration of indeno(1,2,3-cd)pyrene

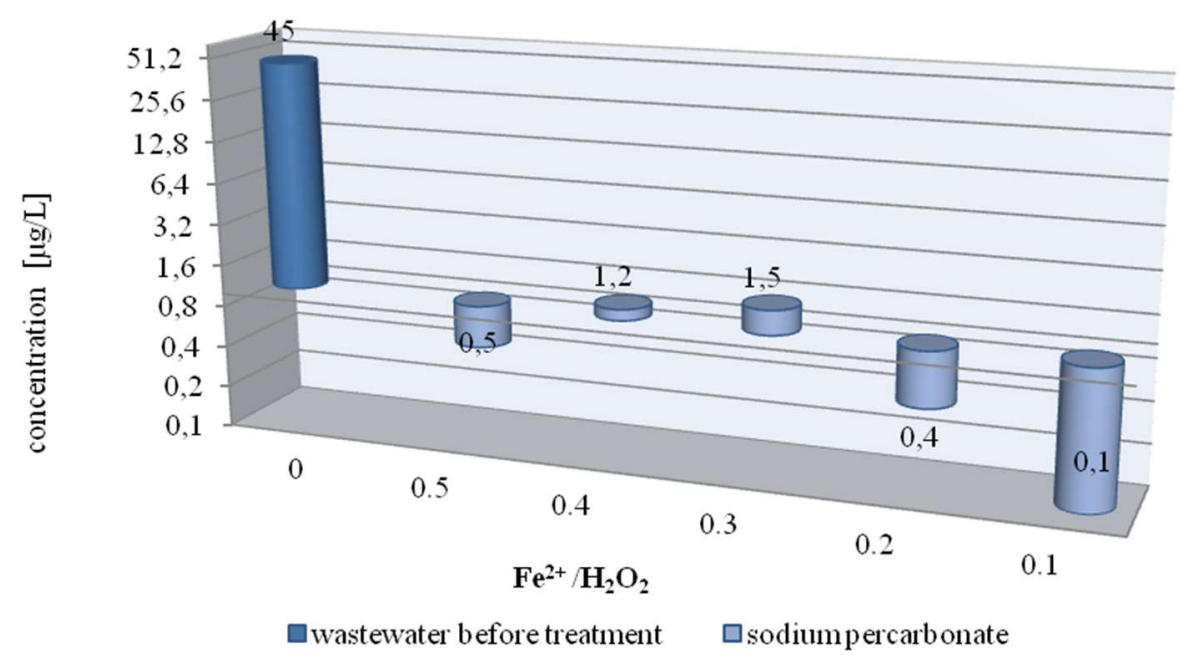

Fig. 10. Changes in the concentration of benzo(g,h,i)perylene 
All doses of the oxidant caused a decrease in the concentration of all tested hydrocarbons in relation to the initial concentration. However, no correlation was observed between the concentration drop and the increase in the oxidant dose. The hydrocarbon concentrations were fluctuated. In Table 2 the percentage changes in the concentration of individual hydrocarbons in dependence on dose oxidant level and statistical evaluation of results are presented. For all hydrocarbons, the decreases in PAH concentrations were statistically significant $(+)$.

Table 2. Range of degradation [\%] and statistical evaluation of results for all tested PAHs (+)

\begin{tabular}{|c|c|c|c|c|c|c|c|c|c|c|}
\hline \multirow{2}{*}{ PAHs } & \multicolumn{6}{|c|}{ Ratio $\mathrm{Fe} 2+\mathrm{H}_{2} \mathrm{O}_{2} /$ significant } \\
\cline { 2 - 14 } & \multicolumn{2}{|c|}{0.5} & \multicolumn{2}{|c|}{0.4} & \multicolumn{2}{|c|}{0.3} & \multicolumn{2}{|c|}{0.2} & \multicolumn{2}{c|}{0.1} \\
\hline $\mathrm{Fl}$ & 96.7 & + & 96.1 & + & 96.2 & + & 98.3 & + & 97.8 & + \\
\hline $\mathrm{Pyr}$ & 97.3 & + & 96.7 & + & 96.0 & + & 98.8 & + & 98.7 & + \\
\hline $\mathrm{BaA}$ & 97.9 & + & 96.7 & + & 95.4 & + & 98.4 & + & 98.0 & + \\
\hline $\mathrm{Ch}$ & 97.9 & + & 96.7 & + & 95.4 & + & 98.4 & + & 98.0 & + \\
\hline $\mathrm{BbF}$ & 98.7 & + & 97.9 & + & 97.5 & + & 98.9 & + & 98.7 & + \\
\hline $\mathrm{BkF}$ & 98.7 & + & 97.9 & + & 97.5 & + & 98.9 & + & 98.7 & + \\
\hline $\mathrm{BaP}$ & 98.1 & + & 97.2 & + & 97.5 & + & 97.9 & + & 98.7 & + \\
\hline $\mathrm{IP}$ & 98.7 & + & 97.7 & + & 97.1 & + & 99.0 & + & 99.2 & + \\
\hline $\mathrm{DahA}$ & $\times$ & + & 95.3 & + & 95.3 & + & $\times$ & + & $\times$ & + \\
\hline $\mathrm{BghiP}$ & 98.8 & + & 97.3 & + & 96.6 & + & 99.1 & + & 99.8 & + \\
\hline
\end{tabular}

$x$ - concentration below the limit of detection

Below the changes in the concentration of $\Sigma 4$-rings PAHs (Fig. 11), $\Sigma 5$-rings PAHs (Fig. 12) and $\Sigma 6$-rings PAHs (Fig. 13) depending on a oxidant level dose has been presented. The highest decrease in the concentration of 4-rings hydrocarbons was noticed for the ratio 0.2 of $\mathrm{Fe}^{2+} / \mathrm{H}_{2} \mathrm{O}_{2}$. In this case, the use of sodium percarbonate under the photo-Fenton reaction conditions, caused degradation of the tested hydrocarbons at the level of $98 \%$. In the case of 
hydrocarbons having 5 and 6 rings, the highest PAHs oxidation efficiency was observed for a ratio at a level 0.1 of $\mathrm{Fe}^{2+} / \mathrm{H}_{2} \mathrm{O}_{2}$. The percentage degradation of 5and 6-rings hydrocarbons tested was $98.7 \%$ and $99.1 \%$, respectively. The efficiency of degradation varied for individual hydrocarbons and ranged from 95.4 to $99.9 \%$

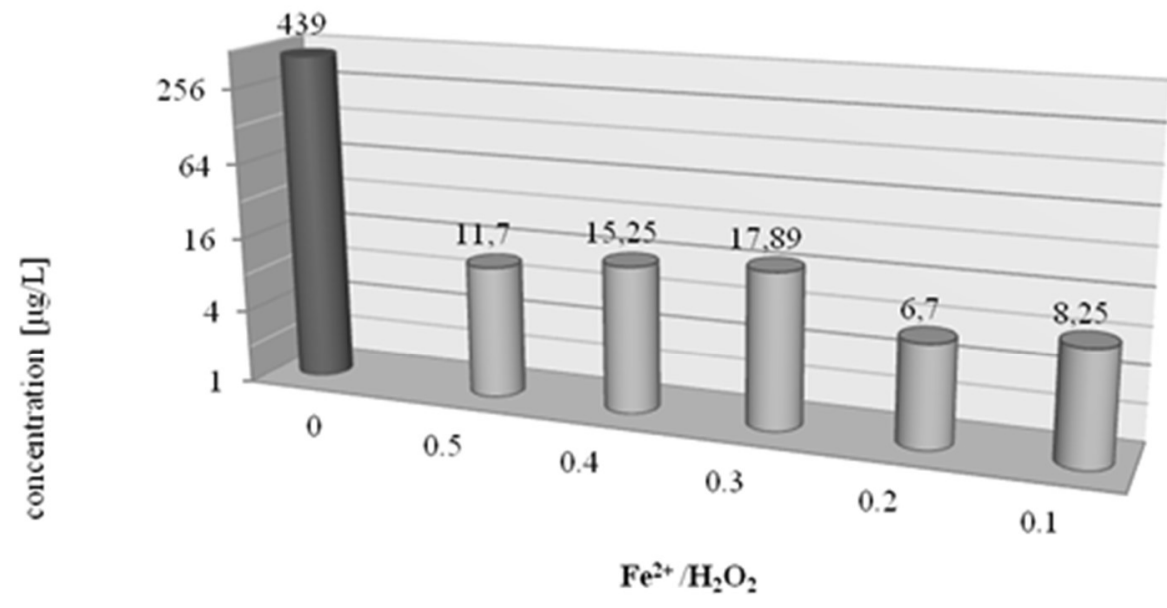

awastewater before treatment $\square$ sodiumpercarbonate

Fig. 11. Changes in the concentration of $\Sigma 4$-rings PAHs

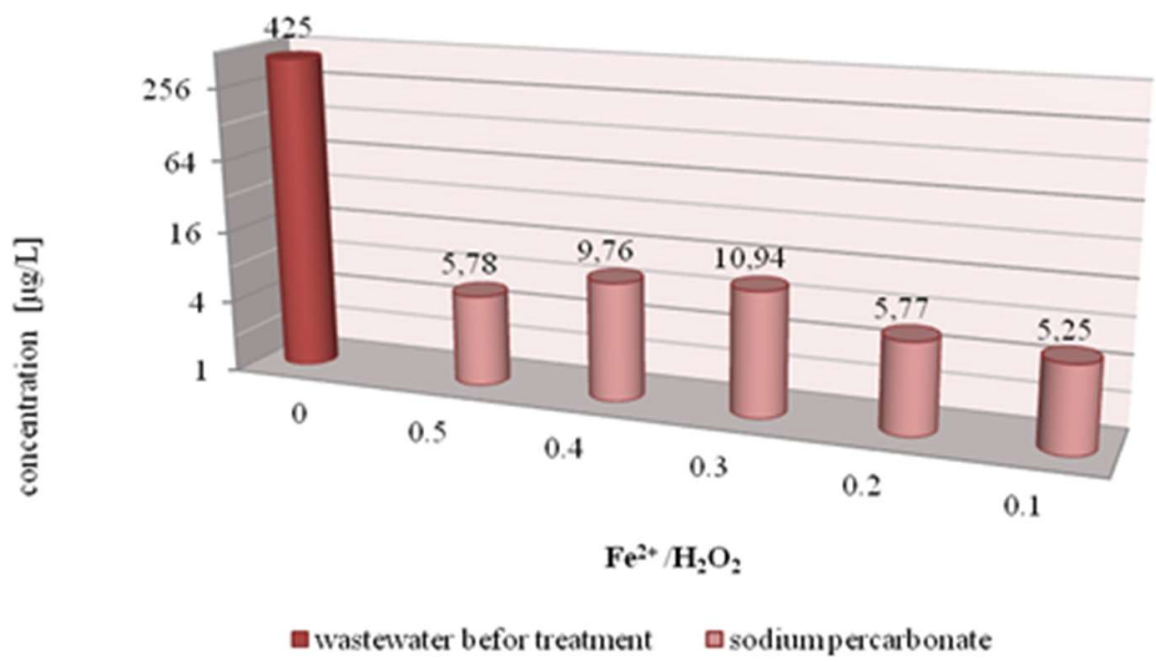

Fig. 12. Changes in the concentration of $\Sigma 5$-rings PAHs 


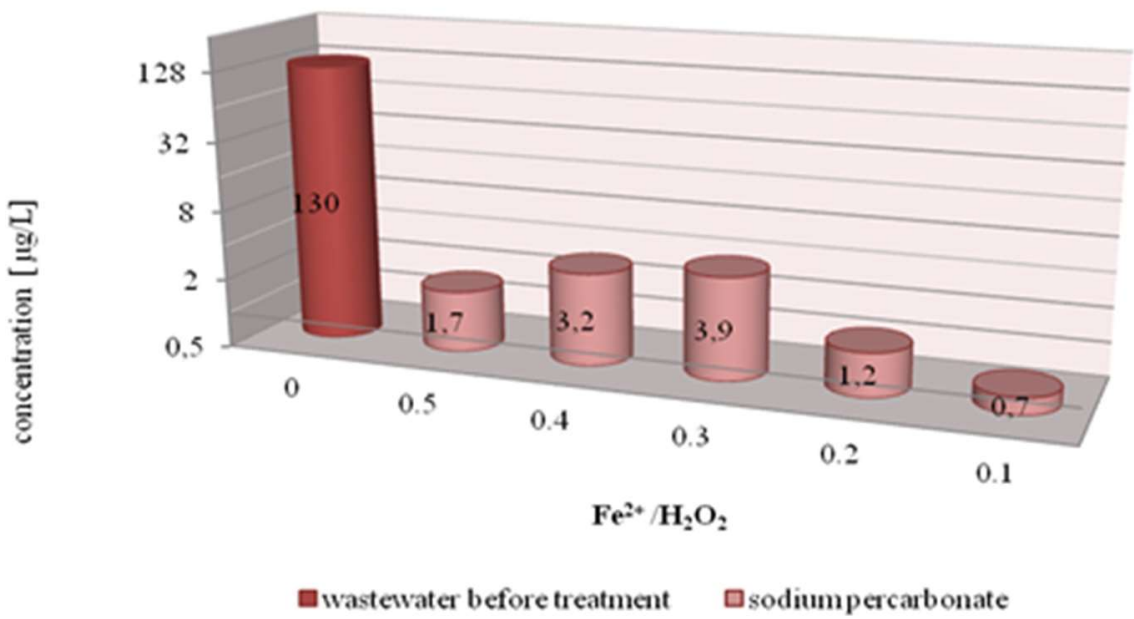

Fig. 13. Changes in the concentration of $\Sigma 6$-rings PAHs

In the Figure 14 changes in the concentration for total of ten tested hydrocarbons, depending on dose level oxidant are presented.

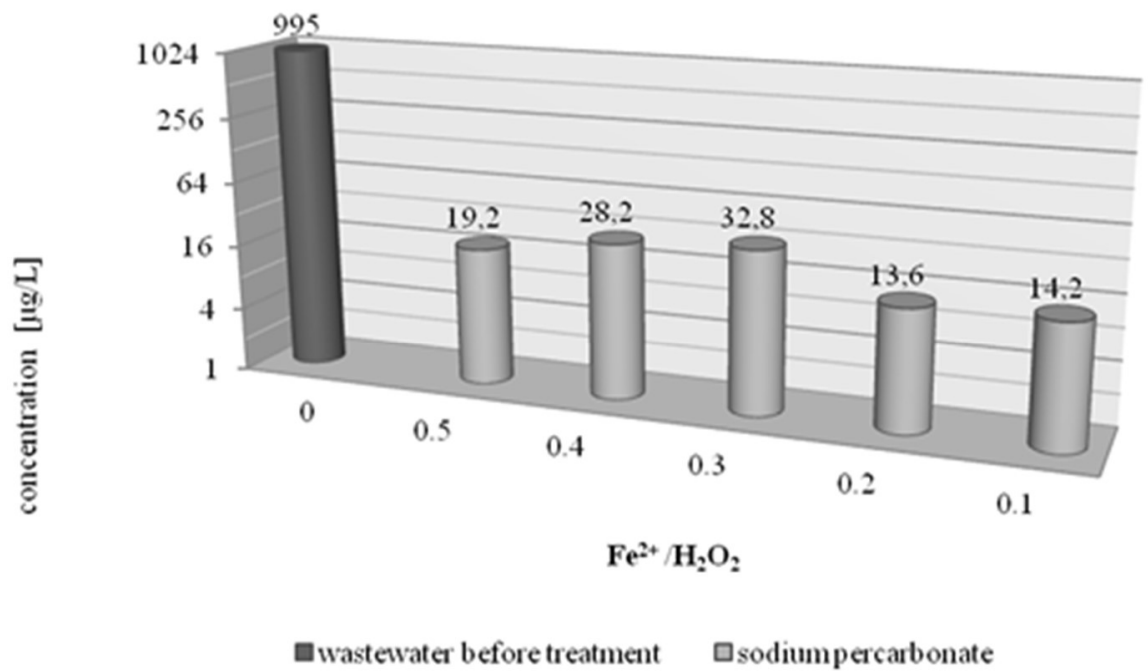

Fig. 14. Changes in the concentration of $\Sigma 10$ tested PAHs

Taking into consideration the degradation efficiency of the sum of 10 tested hydrocarbons under the photo-Fenton reaction condition, the most effective was the ratio 0.2. In this case, use sodium percarbonate allowed to lower concentration to the value $13.6 \mu \mathrm{g} / \mathrm{L}$ compared to the initial concentration at the level $995 \mu \mathrm{g} / \mathrm{L}$. Degree of degradation was $98.6 \%$. 
Data on the effectiveness of advanced oxidation methods for the removal of organic compounds are widely described in the literature. The effectiveness of the Fenton process is influenced by such factors as: the ratio of the hydrogen peroxide ions to the iron ions, the $\mathrm{pH}$ value of the reaction medium, the initial concentration and the type of pollutants and temperature, as well as the presence of reaction inhibitors. Thus, the dose of oxidant and iron ions plays a key role and influence on the effectiveness of the oxidation process. However, too much dose of both reagents can slow down or stop the reaction altogether. Therefore, doses should be selected to ensure consumption all of amount of reagents during the reaction [12]. For example, increasing the concentration of hydrogen peroxide from 50 $\mathrm{mg} / \mathrm{L}$ to $150 \mathrm{mg} / \mathrm{L}$, had an impact on reducing the efficiency of degradation of benzo(a) pyrene by $35 \%$ [13]. Acidic environment of the reaction ensure proper conditions for conducting the Fenton process. The optimal $\mathrm{pH}$ of the reaction environment ranges from $\mathrm{pH} 3$ to $\mathrm{pH} 5$ (optimum $\mathrm{pH}$ 2.8) [14]. However, literature data provided that in the case of PAHs degradation the most effectiveness $\mathrm{pH}$ value depends on the type of hydrocarbon being removed. In an acidic environment anthracene and benzo(a)pyrene were being better degraded, while at $\mathrm{pH}$ value near 7 - fluoranthene and phenanthrene [15]. On the speed and efficiency of the Fenton process are also influenced the initial concentration of pollutants as well as the presence of reaction inhibitors such as carbonates, bicarbonates or sulphides [16]. High temperature (above $50^{\circ} \mathrm{C}$ ) is not recommended because of the faster decomposition of hydrogen peroxide. The exception was benzo(a)pyrene, for which $100 \%$ degradation was achieved at $70^{\circ} \mathrm{C}$ $[13,14]$. In the case of using the photo-Fenton process to degrade the mixture of 16 PAHs in petrochemical wastewater, efficiency was obtained close to $96 \%$, at $53 \%$ reduction of COD value and reduction of toxicity by $50 \%$ [17]. In other studies, which focused on the decomposition of fluoranthene, phenanthrene and aceaphthylene in synthetic water, after the use of the classic Fenton reaction, complete removal of the tested hydrocarbons was achieved [15]. Previous studies by authors have shown that the use of $\mathrm{CaO}_{2}$ under the conditions of the photoFenton reaction allows effective degradation of COD in the range of $30-35 \%$. In the case of PAHs containing from 4 to 6 aromatic rings, the degradation efficiency for individual hydrocarbons ranged from $89-98 \%$ [18].

In the literature, any data about the use of sodium percarbonate under the conditions of the photo-Fenton reaction for cleaning coke wastewater has not been found. However, sodium percarbonate was used in the photo-Fenton reaction for the treatment of industrial wastewater with a COD value exceeding 5,000 $\mathrm{mgO}_{2} / \mathrm{L}$. The effectiveness of removing organic compounds expressed by COD index reached $73 \%$ [19]. Taking into consideration differences in composition of the tested wastewater with data described in the literature and the differences of 
process conditions, it is difficult to compare the results obtained with the data available in the literature.

\section{CONCLUSIONS}

The following conclusions can be drawn based on the results obtained in the research. The total PAHs concentration in coking wastewater before oxidation was about $1 \mathrm{mg} / \mathrm{L}(996,6 \mu \mathrm{g} / \mathrm{L})$. The effectiveness of removal of individual hydrocarbons ranged from $95 \%$ to $99.9 \%$. The highest decrease in the concentration of 4-ring hydrocarbons $(98.4 \%)$ was noticed for the ratio 0.2 of $\mathrm{Fe}^{2+} / \mathrm{H}_{2} \mathrm{O}_{2}$. In the case of 5-rings hydrocarbons, the highest efficiency of oxidation was observed for the ratio of $\mathrm{Fe}^{2+} / \mathrm{H}_{2} \mathrm{O}_{2}$ at the level of 0.1 and 0.2 for which the efficiency was $98.7 \%$. For the 6-rings hydrocarbons, the best ratio was $\mathrm{Fe}^{2+} / \mathrm{H}_{2} \mathrm{O}_{2}$ -0.1 , at which the decomposition of the PAHs tested exceeded $99 \%$. The chemical reactivity of the hydrocarbons studied decreased in the following way: 6-rings PAHs (removal 99.1\%) > 5-rings PAHs (removal 98.7\%) >4-rings PAHs (removal 98.4\%) respectively. The decrease in PAHs concentration was statistically significant for the hydrocarbons tested. During the oxidation process using sodium percarbonate, the decrease in COD and TOC values was in the range of $22-46 \%$ and $10-30 \%$, respectively. Therefore, in the process of photooxidation, not only the degradation of PAHs, but also other organic compounds expressed by COD index and TOC index were obtained. Obtained results confirm that sodium percarbonate can be, with high efficiency, used in the photo-Fenton process for treatment coking wastewater.

Acknowledgement: The research was funded by the projects: BS/MN-402$301 / 17$

\section{REFERENCES}

1. J. Kozak, M Włodarczyk-Makuła: Degradacja małocząsteczkowych WWA $w$ modyfikowanym procesie foto-Fentona, Annual set the Environment Protection, Rocznik Ochrona Środowiska, 20, 2018 - in press (in Polish).

2. H.I Abdel-Shafy, M.S. Mansour: A review on polycyclic aromatic hydrocarbons: Source, environmental impact, effect on human health and remediation, Egyptian Journal of Petroleum, 25, 107-123 (2016).

3. IARC (International Agency for Research on Cancer). IARC Monographs on the Evaluation of Carcinogenic Risks to Humans, Vol. 92: Some Nheteroycyclic Polycyclic Aromatic Hydrocarbons and Related Exposures; International Agency for Research on Cancer: Lyon, France, (2010) 
4. A.T. Lawal: Polycyclic aromatic hydrocarbons. A review, Cogent Environmental Science, 3, 1-89 (2017).

5. M. Włodarczyk-Makuła, E. Wisniowska, A.Turek, A. Obstój: Removal of PAHs from coking wastewater during photodegradation processs, Desalination and Water Treatment, 57, 1262 -1272 (2016).

6. B.R. Lim, H.Y. Hu, K. Fujic: Biological degradation and chemical oxidation characteristics of coke-oven wastewater, Water, Air and Soil Pollution, 146 23-33 (2003).

7. Decree of the Minister of Environment on the requirements which must be achieved when treated effluent are discharged into water and soil and on substances particularly hazardous for water environment (Dz.U.poz.1800,2014) (in Polish)

8. R. Munter: Advanced oxidation processes-current status and prospects, Proccedings of the Estonian Academy of Sciences, 50, 59-80 (2001)

9. M. Cheng, D. Guangming, D. Huang, C. Lai: Hydroxyl radicals based advanced oxidation processes (AOPs) for remediation of soils contaminated with organic compounds-a review, Chemical Engineering Journal, 284, 582598 (2016)

10. R. Andreozzi, V. Caprio, A. Insola, R. Marotta: Advanced oxidation processes (AOP) for water purification and recovery, Catalysis Today, 53, 51-59 (1999)

11. K. Barbusiński: Modification of the Fenton reaction using calcium and magnesium peroxides, Wydawnictwo GIG, Katowice (2006) (in Polish).

12. A. Rubio-Clemente, R.A. Torres-Palma, G.A. Penuela: Removal of polycyclic aromatic hydrocarbons in aqueous environment by chemical treatments: A review, Science of the Total Environment, 478, 201-225 (2014)

13. V. Homem, Z. Dias, L. Santos, A. Alves: Preliminary feasibility study of benzo(a)pyrene oxidative degradation by Fenton treatment, J. Environ. Public. Health, 2009 1-6 (2009).

14. J.J. Pignatello, E. Oliveros, A. MacKay: Advanced oxidation processes for organic contaminant destruction based on the Fenton reaction and related chemistry, Crit. Rev. Environ. Sci. Techol., 36, 1-84 (2006).

15. F.J. Beltrán, M. González, F.J. Rivas, P. Álvarez: Fenton reagent advanced oxidation of polynuclear aromatic hydrocarbons in water, Water, Air and Soil Pollution, 105, 685-700 (1998).

16. K. Barbusiński: Intensyfikacja procesu oczyszczania ścieków i stabilizacji osadów nadmiernych $z$ wykorzystaniem odczynnika Fentona, Zeszyty Naukowe Politechniki Śląskiej, Gliwice (2003) ( in Polish).

17. O.R.S Da Rocha, R.F. Dantas, M.M.M Bezerra, M.M. Lima, V. Lins: Solar photo-Fenton treatment of petroleum extraction wastewater, Desalination Water Treatment , 51, 5785-5791 (2013). 
18. J. Kozak, M. Włodarczyk-Makuła: Photo-oxidation of PAHs with calcium peroxide as a source of the hydroxyl radicals, E3S Web of Conferences, 30, 1-8 (2018).

19. M. Thomas, B. Białecka, D. Zdebik: Removal of organic compounds from wastewater originating from the production of printed circuit boards by UVFenton method, Archives of Environmental Protection, 43, 39-49 (2017).

\section{ZASTOSOWANIE NADWĘGLANU SODU W REAKCJI FENTONA DO UTLENIANIA WWA}

\section{Streszczenie}

Celem pracy było określenie efektywności usuwania 4, 5 i 6 pierścieniowych WWA $\mathrm{z}$ oczyszczonych ścieków koksowniczych $\mathrm{z}$ zastosowaniem nadwęglanu sodu $\mathrm{Na}_{2} \mathrm{CO}_{3} \cdot 1,5 \mathrm{H}_{2} \mathrm{O}_{2}$ i siarczanu żelaza w środowisku kwaśnym. Próbki eksponowano na działanie promieni ultrafioletowych. Źródłem promieniowania UV-C była lampa emitująca fale o długości $\lambda=264 \mathrm{~nm}$, umieszczona bezpośrednio nad warstwą próbek ścieków. Dawki nadwęglanu sodu $\mathrm{Na}_{2} \mathrm{CO}_{3} \cdot 1,5 \mathrm{H}_{2} \mathrm{O}_{2}$ zostały określone na podstawie obliczeń stechiometrycznych. Stosunek jonów żelaza do nadtlenku wodoru uwalnianego podczas reakcji wynosił: 0,$5 ; 0,4 ; 0,3 ; 0,2 ; 0,1$. Przed i po procesie utleniania oznaczano wartość ChZT i OWO oraz stężenia wybranych WWA. Całkowite stężenie badanych WWA przed utlenianiem osiągnęło wartość $995 \mu \mathrm{g} / \mathrm{L}$. Średnia zawartość zanieczyszczeń organicznych określona przez chemiczne zapotrzebowanie tlenu (ChZT) wynosiła 538 $\mathrm{mg} / \mathrm{L}$, podczas gdy średnia zawartość całkowitego węgla organicznego (OWO) wynosiła $180 \mathrm{mg} / \mathrm{L}$. Podczas procesu odnotowano utlenianie zanieczyszczeń organicznych i obniżenie ChZT i OWO w następujących zakresach: $22-46 \%$ i $10-30 \%$. Dla poszczególnych WWA wydajność degradacji wynosiła od ponad $95 \%$ do $99,9 \%$. Efektywność degradacji 4- pierścieniowych węglowodorów wynosiła $98 \%$, a 5 i 6 pierścieniowych odpowiednio $98,7 \%$ i 99,4\%.

Słowa kluczowe: reakcja foto-Fentona, nadwęglan sodu, GC-MS, oczyszczone ścieki koksownicze, WWA

Editor received the manuscript: 15.06 .2018 